\title{
When the Author Sued for Exploitation of Women and Nature in Margaret Atwood's Surfacing
}

\author{
Silvia Rosa ${ }^{1 *}$, Riyani Vadilla ${ }^{2}$, Dina Fauzana ${ }^{3}$, Mahawitra Jayawardana $^{4}$ \\ Andalas University, Faculty of Humanities ${ }^{1}$ \\ Andalas University, Postgraduate Program in Literature ${ }^{1}$ \\ \{sylvierosha2@gmail.com¹ silviarosa@hum.unand.ac.id ${ }^{2}$ \}
}

\begin{abstract}
Women and nature often experience violence. The research aims to describe the forms of female exploitation and nature represented in Margaret Atwood's Surfacing. Data collection is done through library studies. Vandana Shiva and Maria Mies' ecofeminism theory used to for analyzed the data. The results showed that the Surfacing novel represents three forms of exploitation experienced by women and nature. The three forms of exploitation are (1) reduction of the female uterus by the presence of technology; (2) exploitation of women and nature due to industrial interests; (3) Development and tree logging for the benefit of various industries. The study concludes that women are positioned as objects and 'the other' exploited by the capitalist patriarchy. Women are used for commercial gain, without thinking about the impact of ecological destruction that can afflict women and nature. Women are guardians of biodiversity and sustainability of life because it utilizes nature to fulfill daily life needs. Ecological crises and exploitation of women must be prevented. Those messages are presented in this novel.
\end{abstract}

Keywords: exploitation; women; nature; Surfacing; ecofeminism

\section{Introduction}

Women and nature are often victims of male exploitation, which causes them to be oppressed in Europe's patriarchal societies, which has widely developed an ecological crisis. In this case, the high ego of masculinity, violence and discrimination become a main factor of oppression on women and nature. Both exploitation women and nature, has created an ecological crisis. There is a sharp dichotomy between women on the one hand and men on the other; also nature on the one hand with culture on the other. The patriarchal system that has developed widely in most societies has created a strict separation between women and nature and nature and culture. The phenomenon of separation is a picture of the reality of everyday life both in the third world and in developed countries.

Women are often not involved in natural exploration practices controlled by state and private companies. Besides that, women's contribution to utilizing nature to meet their daily needs is also underestimated and is considered to have no contribution value to the country. The presence of modern science. On the other hand, it also negates non-Western traditional 
knowledge controlled by Third World women. This phenomenon has inspired various writers of literary works in multiple parts of the world from the 1970s to the present time in writing literary works. Some of these authors include Margaret Atwood, Barbara Kingsolver, Anindita S. Thayf, Doris Lessing, Carol Warner, Alice Munro, and Jeanette Winterson. They are writers who care about what happens to women and nature.

Margaret Atwood is an intense and concerned woman writer to voice the problems felt and faced by women. One of her works, entitled Surfacing [1], tells the problem's story. This novel was first published in 1972. Surfacing tells the story of a woman's journey with her boyfriend and two friends who are also married to North Quebec.

The female character is not named (unnamed character). She and herboyfriend, Joe, and two friends named Anna and David are trying to find their father who has been missing so long. During her journey and also after arriving at her childhood house [2]. The feminine world's oppression and nature is directly a force and domination in which the feminine principles are earth, body, emotions, and irrationality.

In contrast, masculine principles are represented by rationality, culture, and logic. The narrator considers herself comparable to the natural world and refuses to be trapped in the patriarchal trap that destroys her. Surfacing raises the minimum price, but in one sense, the desire to break dualism with the Atwood power [3].

Meanwhile, male, female dualism, human, culture, subject, object, nature, and animal are also found. Atwood describes women and nature's image equally with specific tasks such as Mother Earth [4]. Artistically, Atwood's language is exact with Halliday's conception, which states that discussion is semiotic social, the discussion of which is a social process, and social reality is a dialectic complication. A language doesn't redirect a nonpartisan world view, however a male centric view which at last forces an insignificant and restricted picture of female [5]. Surfacing describes a deception strategy that is not recognized as an attempt to survive by a woman in a patriarchal society, including in language [6]; [7]. This novel also shows subaltern rebellions against the patriarchal situation, which confines them and equates themselves naturally [8]. Surfacing, published for the first time in 1972, envision the ecological disaster situation that would affect the world in the 21st century [9]. This study was conducted to complement other aspects of the science of the novel Surfacing, particularly concerning the mental images experienced by women from the perspective of female authors. How female authors discuss the problems faced by women in the works they write.

\section{Methodology}

This study is qualitative. The primary data come from words, sentences, paragraphs, and discourses contained in the Surfacing novel. The data analysis took place in a descriptiveanalytical manner by comparing the data with the concept of feminism. The retroactive reading process is carried out to reach a deep and detailed understanding of the Surfacing novel's violence and natural exploitation. 


\section{Results and Discussion}

\subsection{Result}

Surfacing presents several descriptions of the exploitation of women, as shown in the following table:

Table 1. Narrative on the Exploitation of Women and Nature in Surfacing

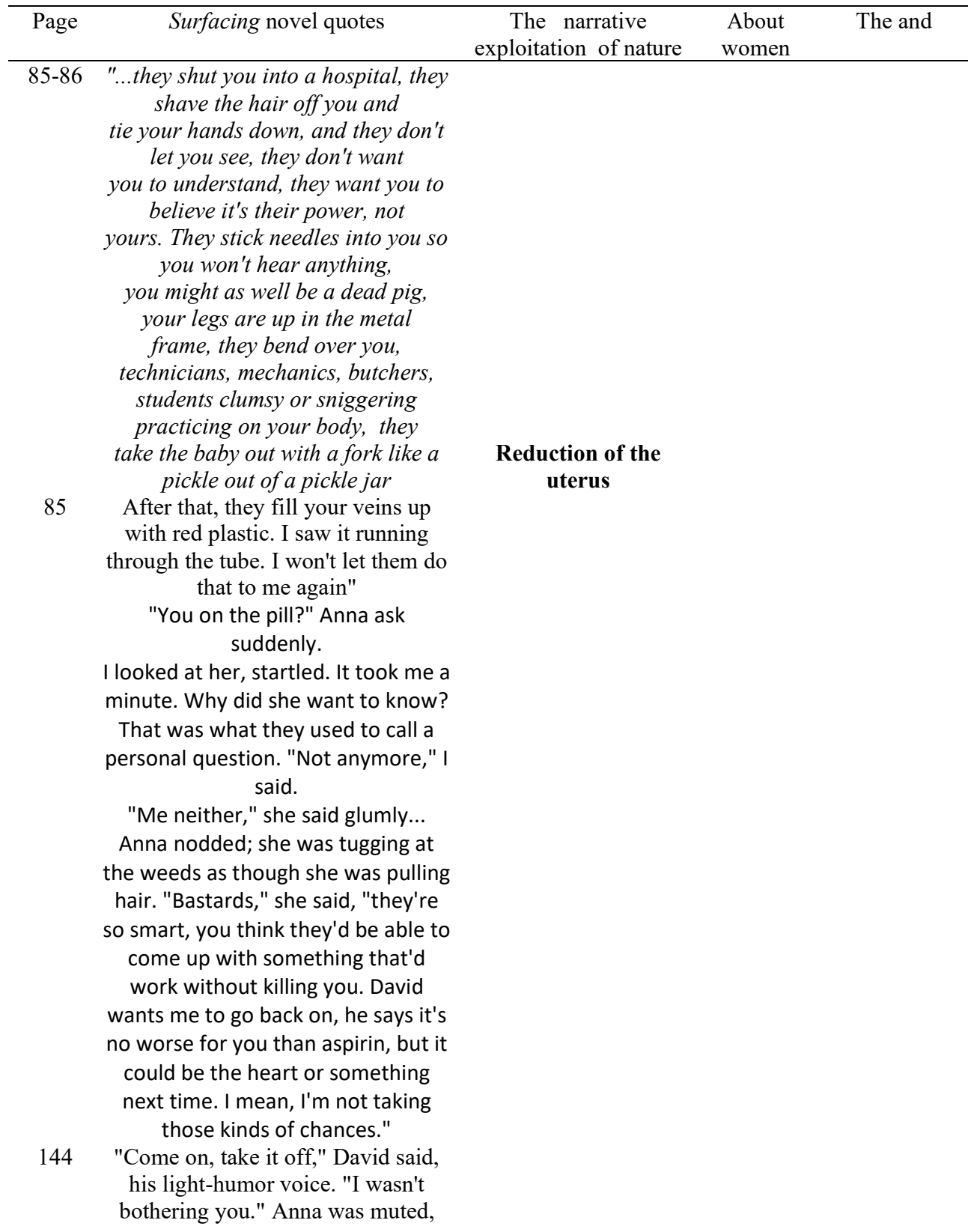


avoiding.

"It won't hurt you, and we need a naked lady."

"What the hell for?" Anna was peevish now, her veiled head upturned; her eyes would be squinting.

"Random Samples," David said patiently..." You'll go in beside the dead bird, it's your chance for stardom, you've always Pornography of women wanted fame. You'll get to be on Educational T.V." he added as though it was a special bribe

$127 \quad$ "..., at that time, I was afraid there was a machine that could make people vanish like that too, go nowhere, like a camera that could steal not only your soul but your body also."

101-102 "I believe I can speak for the rest of Michigan members in

saying we'd be prepared to make you an offer."

"What for?" I said. He sounded as though he wanted me to buy something, a magazine or a membership.

He swept his pipe in a semicircle. "This lovely piece of property," he said. "What we'd use it for would be a kind of

retreat lodge, where the members could meditate and observe,"

he puffed, "the beauties of nature.

And maybe do a little hunting and fishing. [----] "Well, we'd have to install a power generator, of course, and a septic tank; but apart from that, no, I expect

we'd like to leave it the way it is, it has definite," he stroke his mustache, "rural charm."

122 "Chainsaw, I could see them now,

Violence against

nature

two men in yellow helmets. They'd left a trail, trees felled at intervals into the bay, trunks cut cleanly as though by a knife. Surveyors, the paper company, or the government, the power company. If it was the power company, I knew what it meant: they were going to raise lake level as they had sixty years ago. 
They were plotting the new shoreline. Twenty feet up again, and this time they wouldn't cut off the trees as they had before. It would cost too much; they would be left to rot. The garden would go, but the cabin would survive; the hill would become an eroding sand island surrounded by dead trees."

(Source: Atwood, 1983)

\section{Discussion}

\subsection{Reduction of Women's Uterus with the Presence of Modern Science}

The reduction of women's wombs is represented by abortion behavior. Sexism in the reduction of a woman's uterus occurs when the narrator tells of her bad experiences related to medical personnel's treatment when carrying out an abortion of the fetus she is carrying. The narrator thinks these tools should not be attached to her and the treatment traumatizes her. This action indicates that women's role as a private right of women has been violated to be transformed into a non-private area. Medical equipment sourced from scientific advances has reduced the privacy of women towards their positions. Shiva mentions that women's roles are reduced to helpless vessels, and women's passivity has been engineered in line with their ignorance [10]. Reduction of women's grievances is avoided according to pages 85-85 listed in the previous table 1 .

The technological intervention in the quote shows that women are victims of gender bias by modern science that develops in masculine societies. As Shiva and Mies pointed out where new developments in reproductive technology, genetic engineering, and biotechnology have made women very aware of the gender bias of technology and science, and the whole paradigm of science is anti-natural, colonial, and patriarchal characteristics that try to keep women away from their generative power as well as the productive forces of nature [10].

The reduction of the female uterus was presented by Atwood in Surfacing novel in the form of abortion and in the form of a contraceptive, which is a pregnancy delay pill. The presence of contraceptives alienates women from modern science, which makes them an object of experimentation and, at the same time, reduces their ability to reproduce. The reduction of the uterus in Surfacing novel shows how women are no longer seen as humans, individuals, and as an inseparable unit, but as objects of reproductive technology experiments.

The reduction of a woman's uterus is also illustrated by Anna's behavior, asking the narrator whether she is taking contraceptive pills. Anna tells the narrator that she is forced by David to take the pill. David thinks taking the contraceptive pill is the same as taking aspirin. However, these pills have side effects on women who take them. The data quotation in the previous table 1 , especially those on page 85 , describes the ugly situations suffered by women who take contraceptive pills.

From the excerpt on page 85 , it is clear that the womb of women is not immune from the invasion of reproductive technology, to the point that the capitalist patriarchy controls women's fertility, and it is as if they do not care about the side effects of contraceptive pills on women when consumed. Klein in Shiva and Mies also revealed that many women complain of infertility due to destructive contraceptive methods such as the Dakon Shield, IUD, and doctor's treatment without feeling [10]. The reduction of women's womb is nothing but a form 
of domination waged by capitalist patriarchy over women. In practice, capitalist patriarchy implements a male/female dualism where women are at the bottom. It is the human way of thinking that is blocked by this dualism that Atwood opposes in Surfacing.

As we all know, modern science is currently oriented towards the West, which is ruled by white male scientists. When the protagonist tells how traumatic she is in facing an abortion, it indicates that Atwood has invited readers to understand that there has been a reduction in the female uterus that has been done by capitalist patriarchy by utilizing modern science that applies universally but is both patriarchal and at the same time oppressing women.

\subsection{Pornography of Women and Exploitation of Animals for Commercial Purposes}

The objectification of women for commercial purposes seems to be considered normal. Women's bodies are exploited, as seen in Anna's character in Surfacing. Anna was filmed and videotaped naked by her husband. The video was made for her husband's satisfaction, named David, and to repay Anna for having an affair with Joe, the narrator's lover. Besides, the video was aimed at making a film called Random Samples. The data citation on page 144 listed in Table 1 illustrates how helpless Anna is in refusing David's request.

The action of the character David who forces Anna to do this, indirectly shows the domination exercised by the capitalist patriarchy towards women. Women are depicted as weak and powerless to fight against the domination that is being waged. The designs of power that tend to view women as soft are the patterns found in Western capitalist societies that always try to get maximum profit in their daily lives. In this case, the interest of the industry has also taken part in uprooting the role and function of women and nature, which is seen in the character David who mentions the indecent scenes he recorded were used for the film Random Samples. Pornography, according to Shiva and Mies, is a clear example of the relationship between lust and violence, and fantasy and desire that introduces men to the image of certain parts of the female body that produces a pornographic viewpoint. This view of porn is a source of economic growth in the form of highly commercial advertising with a flood of magazines, television, videos, films, and others [10].

The quote indicates that science has committed violence against women and nature. Anna is represented by women, while the dead bird represents nature. The camera is nothing but a symbol of modern science that oppresses women and nature. Besides, the violence against women in the form of pornography experienced by Anna's character is also a "form of marginalizing women and nature from men and culture" [11]. This marginalization has hurt and exploited both women and nature.

On the other hand, David's act of filming his naked wife with the camera is also used by Atwood to underline his dislike for the development of science, which exploits humans, especially women, who are the beneficiaries of knowledge. Cameras are seen as a tool that takes the human soul. This view of rejection was conveyed by Atwood through the data excerpt on page 127, as described in the previous table 1 .

The quotation on page 127 also further emphasizes that modern reductionist science has attempted to conquer and reduce women and nature's ability in productivity. Besides that, it has dichotomized the relationship between humans and nature. Nature is no longer treated as a feminine principle of "Prakriti," which represents everything in this world and is instead treated as a subordinate treated at will and oppressed.

\subsection{Development and Tree Logging for the benefit of various industries}

The issue of exploiting women and nature for the benefit of multiple industries in building and cutting down trees also occurs in Surfacing novel. The industries mentioned 
contribute to the exploitation of wildlife, including the paper industry, the hydropower industry, the entertainment industry, and the tourism industry. Development in the tourism industry is conveyed in Surfacing through the character Paul, a friend of the narrator's father who wants to turn the narrator's cottage into a retreat lodge. That cabin is managed to bring in tourists. The narrator did not approve of this wish. The effort to turn the house into a retreat lodge indicates capitalist patriarchy's efforts that harm nature. Nature that is already beautiful without human intervention is then transformed into an object to get maximum profit and capital accumulation. Women's rejection of natural destruction is illustrated through the quotation on pages 101-102, as stated in Table 1 .

As revealed in the quotes on pages 101-102, the capitalist patriarchy's desire to be able to exploit nature is not far from the exploitation itself, including hunting, fishing, and taking advantage of the charm of the countryside to make tourist attractions. Hunting, fishing, and tourism activities can destroy the already beautiful nature and disrupt the surrounding natural ecosystem. Hunters will target the birds, and the fish in the lake will be the catch of the anglers so that over time their population can be threatened with extinction. Nature is treated as something lower than humans because capitalist patriarchy applies anthropocentrism (human-centered). Besides, capitalist patriarchy considers the exploitation of nature as a normal and natural thing. It views both nature and women as objects, and 'Others' as Shiva mentions in masculine societies, men's domination over women and nature causes them to see natural women as 'the Other.' Non-passive self [12].

Another form of exploitation of nature in the Surfacing novel is shown through illegal logging, as explained by quoting the data on page 122, shown in Table 1. As stated in the quote, through Surfacing, Atwood invites his readers to become aware of the Canadian government and the private sector's exploitative and dominating policies. As mentioned in the above quotation, the efforts of various parties, namely survey officers, paper companies or the government, and electricity companies, reflect that the capitalist patriarchy no longer sees land as a sanctified mother and positions itself as the owner of nature. The intervention of various parties over land management in Surfacing novel also shows that colonialism and capitalism have plundered nature. In the sense of the word, the character is not treated as Mother Earth or sacred land but instead is treated as an object for commercial purposes. If viewed from Shiva and Mies' theory, this forest exploitation effort means that it has committed violence against nature. Forests for women are nothing but food for their lifetime, and maintaining the viability of biological resources is very important for the feminine use of forests [13]. Apart from that, from an ecological perspective deforestation is for commercial purposes besides destroying the existing ecosystem structure. It also destroys nature's regenerative power to renew itself.

Besides, there is an indication of the electricity company's reservoir development plan in the above quote. A reservoir development plan is a form of unbalanced development by alienated men who exploit women and nature. As revealed by Shiva, either nature or women are designed into passive objects that not only utilized as means of satisfying male passions but also exploited brutally and ostracized by men. Nature and women who created and sustained life are reduced by capitalist patriarchy to what Shiva calls 'resources' in the fragmented anti-life development model [12]. 


\section{Conclusion}

Thus, it can be concluded that exploitation of women and also nature in Margaret Atwood's Surfacing is seen in two major things, namely the reduction of the womb of women in the presence of modern science and the exploitation of women and nature for the interests of various industries by capitalist patriarchy. Nature and women are treated like objects or "the other," which are exploited for humans' benefit. Animals and plants are, without exception, used in a way that is not good, namely being shot, then hanging like a cross, and trees being felled for the benefit of the paper and electricity industries. Men also consider themselves to have dominance over women and instead use women's bodies to gain an advantage. The dualism of man/woman and man/nature that Atwood has explained in Surfacing in the hope that readers will realize the exploitation of nature and women has hurt the feminine principle of 'Prakriti' which invites humans, both men, and women, to live side by side with nature and ending the domination of the patriarchal capitalist and oppressive society.

\section{References}

[1] M. Atwood, Surfacing, General Pa. U.S.A: Mc Clelland and Stewart Limited, 1983.

[2] A. Bhalla, "Ecofeminism in Margaret Atwood's Surfacing," vol. 2, no. 10, pp. 16, 2012.

[3] Y. Khan, "The Power and Promise of Ecofeminism A Study of the Selected Novels of Margaret Atwood and Alice Walker," 2014.

[4] Z. Koukhaei and S. Afrougheh, "New Perspective in Women and Nature: Dualism in Margaret Atwood's Surfacing," Int. Res. J. Appl. Basic Sci., vol. 4, no. 11, 2013.

[5] J. J. Weber, Critical Analysis of Fiction: Essays in Discourse Stylistics, Rodopy B.V. Amsterdam,Netherlands: Rodopi, 1992.

[6] C. Kerskens, "Escaping the Labyrinth of Deception : A Postcolonial Approach to Margaret Atwood's Novels Volume I," vol. I, 2007.

[7] R. M. Jennings, "Disappearance In Deceptive Landscapes: Borderlines Of Identity In The Canadian Wilderness With Particular Reference To Selected Works By Margaret Atwood, Robert Kroetsch, Michael Ondaatje And Aritha Van Her," The University of York, 1996.

[8] C. Nicolaescu, "The voice of subaltern in margaret atwood's Surfacing: An anticolonialist approach to the novel," J. Res. Gend. Stud., vol. 5, no. 2, pp. 350355, 2015.

[9] M. Kiran, "Ecofeminism in Margaret Atwood's Surfacing and Kamala Markandaya's Nectar in a Sieve," Motifs An Int. J. English Stud., vol. 3, no. 2, 2017, doi: 10.5958/2454-1753.2017.00014.9.

[10] V. Shiva and M. Mies, Ecofeminism: persepktif gerakan perempuan \& lingkungan, Terjemahan.Yogyakarta: IRE Press, 2005.

[11] R. P. Tong, Feminist Thought: Pengantar Paling Komprehensif kepada Arus Utama Pemikiran Feminis, Terjemahan. Yogyakarta: Jalasutra, 2006.

[12] V. Shiva, Staying Alive: Women, Ecology and Survival in India, vol. 84, no. 7. New Delhi. India: Indraprastha Press, 1988.

[13] V. Shiva, Bebas dari pembangunan : perempuan, ekologi dan perjuangan hidup di India,Terjemahan. Jakarta: Yayasan Obor Indonesia, 1997. 